Genij Ortopedii, Vol. 25, no 4, 2019

(C) Krivenko S.N., Medvedev D.I., 2019

DOI 10.18019/1028-4427-2019-25-4-580-587

\title{
Current treatments for patients with multifragmentary fractures of the distal humerus (literature review)
}

\author{
S.N. Krivenko ${ }^{1}$, D.I. Medvedev ${ }^{2}$
}

${ }^{1}$ Donetsk Gorky National Medical University, Donetsk

${ }^{2}$ Donetsk Republican Trauma Center, Donetsk

\begin{abstract}
Multifragmentary fractures of the distal humerus have traditionally presented a treatment challenge for the orthopaedic surgeon because of the growing incidence, severity of injury and compromised elbow joint function. This is a comprehensive review of the current literature that details treatment options of distal humerus fractures. Objective Our aim in this article is to provide the readers with a review of current approaches to the treatment of multifragmentary fractures of the distal humerus.
\end{abstract}

Keywords: treatment, osteosynthesis, multifragmentary fractures, distal humerus

Fractures of the distal humerus have traditionally presented a treatment challenge for the orthopaedic surgeon because of the growing incidence and severity of injury. Disability rates are reported to be rather high [1, 2]. Distal humerus fractures represent $79.5-89.0 \%$ of all intra-articular injuries [1]. Fractures of the humerus condyles constitute 0.5$2.0 \%$ of all injuries to musculoskeletal system, 6.5-15.0\% of humerus fractures and $30 \%$ of elbow fractures $[3,4,5,6,7]$. Contracture of the elbow is a common complication due to extended period of joint immobilization and occurs in up to $85 \%$ of the cases [8-17].

Several series performed in early 60-es of the last century showed negative effects of prolonged immobilization on elbow function $[16,17,18,19]$. The combination of anatomic complexity, multifragmentary comminution, specific biomechanics and limited capacity of the hyaline cartilage to regenerate renders these fractures difficult to treate successfully and often make a full restoration of function uncertain. Intra-articular injury to the elbow is accompanied by destruction of the articular cartilage with progression of degeneration period being shorter and the development of osteoarthritis being inevitable. Morphology of para-articular tissues, vessels and nerves of elbow bursa and ligaments is close to the perisoteal structure so that a fracture heals with diaphyseal periosteal osteogenesis, and hyaline cartilage regeneration is ceased at the stage of nondifferentiated fibrous tissue. So, passive exercises can be recommended for repair of intra-articular injuries to regain functional elbow motion at early postoperative period [19]. Methods that would allow early restorative treatment of the involved joint is given priority in repair of multifragmentary fractures of the distal humerus encouraging functional use of the limb [19].

Evident injury to the tissues at open reduction and internal fixation is accompanied by reaction of paraarticular tissues and muscles to surgical trauma and results in heterotopic ossification in $28.2-49.0 \%$ of victims [20, 21, 22, 23, 24]. Permanent disability due to above complications is observed in $30 \%[1,4,13$, $14,20,21]$. The ultimate goal of rehabilitation after a fracture is to facilitate osseous healing and restore full motion and strength of the upper limb [25, 26, 27]. There is also a need to maximally restore anatomical articular congruence, if possible [19].

Multifragmentary fractures of the distal humerus are characterized by a variety of fragments' location including intra-articular location, comminuted fragments sized 0.5 to $2.0 \mathrm{~cm}$ in the metaphysis and/or articular portion of the humerus and deficient osseous tissue. Extensive injuries to juxtaarticular structures and massive hemmorhages in the surrounding soft tissues, considerable bone displacement can be observed with resultant 
osteoporosis developing in the distal humerus. These factors impede appropriate recovery of the elbow joint and lead to a high rate of poor outcomes $[2,28]$. The Comprehensive Classification of Long Bone Fractures is helpful in presenting the most relevant fracture patterns and idenfying proper treatment strategy [29].

Several classifications were offered for distal humerus fractures with the most comprehensive AO classification that describes fracture patterns and location, type and extent of dislocation and fragments' size [30]. The classification includes extra-articular and supracondylar fractures, intra-articular, transcodylar-supracondylar largefragmental injuries and comminuted fractures. Comminuted intra-articular distal humeral fractures present a significant challenge. It should be noted that all types of distal humerus fractures involve elbow joint and inadequate treatment can result in severe elbow function, flexion and extension contractures, in particular [19].

Okhotsky et al. (1991) used to focus on restoration of articular congruity to enable early elbow motion with appropriate treatment provided. Traditionally, non-operative and surgical techniques are used to repair distal humerus fractures. Non-operative treatment is normally reserved for slightly displaced fractures: bone translation of not more than $3 \mathrm{~mm}$ and distasis of not more than $3 \mathrm{~mm}$ and lateral or medial columns rotated by not more than 35 degrees [31, 32, 33, 34, 35, 36]. Long term immobilization of up to 5-6 weeks leads to the formation of expressed contractures and prevents early functional restoration of the elbow joint.

The system of continuous skeletal traction (SCST) was widely used for the repair of distal humerus fractures with indications [28] including:

1) neglected fractures of the distal humerus ( 3 to 7 days after injury);

2) trophic disorders of soft tissues being a contraindication to manipulations at the site;

3) secondary bone displacement following acute closed reduction or its failure;

4) neurological disorders;

5) considerably displaced bone fragments.
However, SCST is associated with long term bed rest as a particular disadvantage [37, 38, 30, 40]. Other disadvantages include:

1) imperfection of the traction loop attached to the forearm;

2) absence of countertraction loop to address distal ulnar displacement;

3) incomplete bone immobilization;

4) probability of superficial/pin tract infection;

5) prolonged bed rest causing deleterious physiological effect.

Combination of the above factors leads to the development of edema, paresis, pain, adduction contracture of the glenohumeral joint and flexionextension contraction of the elbow [28]. Unsatisfactory outcomes of SCST are caused by:

1) delayed consolidation;

2) persistent elbow deformity;

3) nonunions with soft tissue interposition in a fracture gap [33].

Osteosynthesis with external fixation devices is effective for monofragmentary types A1, B1 and $\mathrm{C} 1$ fractures due to complexity of anatomical restitution of the articular surface of the distal humerus. Transosseous osteosynthesis techniques employ a great number of reduction maneuvres that can be tailored to a specific fracture pattern [40, 41, $42,43,44,45,46]$ using a wide array of hardware [47, 48, 49]. Particular advantages of transosseous osteosynthesis include less traumatic procedure and stable bone fixation to ensure optimal conditions for reparative osteogenesis and reduced period of fracture healing. Early range of motion exercises can be initiated from the first postoperative days with elbow externally fixed and unloaded [19, 48, 51]. However, considering specific role of periarticular tissues of the elbow in the formation of joint contractures long term use of multiple wires with external fixation can be harmful for sliding movements of the joint. In addition to that, elbow motion is often accompanied by superficial/pin tract infection, pain and resultant contracture [13, 49]. External fixation devices were shown to be practical for addressing adverse events following distal humerus fractures [51]. The introduction of locking compression plates improved 
the outcome of internal fixation in distal humerus fractures significantly and allowed early mobilization. Open reduction and internal fixation has become the treatment of choice for intra-articular fractures of the distal humerus [8, 24, 52, 53, 54, 55]. Rigid internal fixation of the articular surface to the distal humerus can be produced either with nailing $[8,56,57]$ or with plating $[8,51,58]$.

Open reduction and bone fixation with metal constructs (screws, plates, wires) developed and introduced into clinical practice can be associated with a higher risk of complications [7, 35, 36]. The search for new techniques and devices providing more stable bone fixation is useful to avoid external immobilization and initiate functional elbow restoration early postsurgery.

Olecranon osteotomy is the traditional standard approach to the distal humerus and elbow joint. A V-shaped olecranon osteotomy is performed out of posterior approach creating a wide exposure of the articular surface of the distal humerus making reduction and internal fixation of complex fractures feasible. It should be noted that optimal conditions are created for olecranon healing at the osteotomy site $[60,61]$. The most common method for this is tension-band wiring first described by Weber [62] The technique relies on open reduction and internal fixation and consists of two K-wires inserted from the proximal aspect of the olecranon along the long axis of the ulna (intramedullary), and a tension-band wire loop. Osteosynthesis can also be produced with 6.5 mm cancellous screw or a cancellous screw combined with a tension-band wire loop. Reconstruction plate can be used for osteosynthesis of olecranon fractures.

Reduction of the distal humerus fracture is performed first and held with $\mathrm{K}$-wires. Then the plate is placed and fixed with $3.5-\mathrm{mm}$ locking screws. Care is taken not to impinge on the olecranon and coronoid fossae. Screws and plates are used for stable fixation $[8,34,44,63,64,65]$. Autologous iliac crest bone graft is used to repair a defect of the distal humerus trochlea formed with severely comminuted fragments to be removed [30].

There is a technique of osteosynthesis that suggests fixation of the capitular epiphysis (following reduction) with screws first and then with two pairs of wires placed in major fragments from bottom to top with exit proximally off the fracture site. At the next stage, the prominent wire ends are fixed with 8 -shaped wiring loops placed at the lateral surfaces of the humerus and tightened up creating a constrained system [66]. This method deserves attention and requires further development with its valuable biological features and a small construct size. Plating or combined osteosynthesis is an optimal operative treatment for monofragmentary and large fragment comminuted fractures of the distal humerus $[49,53$, 67, 68, 69, 70, 71].

Bone stability provided by plates and screws has been shown to enhance and construct designs, configurations, reamers, etc. evolve considerably over the years. This facilitated better functionality and less traumatic interventions. New biocompatable metal alloys have been developed for medical implants without loss of mechanical strength.

Double-plating techniques are generally accepted for osteosynthesis of the distal humerus fractures . Dual plating is either an orthogonal configuration, with placement of one plate on the medial column and the other plate along the posterolateral column, or parallel configuration, with placement of one plate on the medial column and the other plate along the lateral column [71, 72, 73, 74]. Little difference in plating configuration, either orthogonal or parallel, was found in biomechanical analyses and no significant difference with regard to clinical outcomes [19]. However, an advantage of parallel plating was emphasized by some surgeons who questioned inadequate fixation stability with orthogonal plating [75].

A comparative study confirmed that orthogonally oriented plates were much stiffer in the sagittal plane than either crossed malleolar screws or a posterior Y-shaped plate. Locking compression plates placed in an orthogonal position showed significant improvement in sagittal bending and torsional stiffness compared with plates placed in a dorsal position [22]. Many surgeons use orthogonal double plating as the preferred method in their clinical practice. Parallel plating has become an attractive 
option for fixation of distal humerus fractures with pre-contoured, indication specific plates. The precontoured parallel plates are fixed to the bone using three cortical screws placed proximal to the fracture line and three distal [76]. Additional implants to be placed into the capitular epiphysis are needed to ensure better stability in some cases. Compression headless screws, threaded Kirschner wires, bioresorbable pins are used for this purpose avoiding contact with screw plate fixation.

Benefits of plating osteosynthesis include image intensifier control for bone reduction and a short hospital stay. Image intensifier control facilitates more accurate reinstitution of the articular geometry of the glenohumeral joint for functional elbow recovery, and a shorter hospital stay is associated with reduced costs for care and psychological and emotional wellbeing of patients $[8,30,31,77]$. The proper balance between biomechanical and biological priorities is important for the execution of a preoperative plan and may require intraoperative modifications in repair of multifragmentary and comminuted fractures.

Therefore, there is a variety of treatment modalities offered for reapir of multifragmentary fractures of the distal humerus with non-operative and surgical techniques. Surgical treatment in most cases requires anatomic reduction and fixation with lag screws or plates and screws depending on the complexity of the fracture. Plating techniques and combined metal osteosynthesis provide solid fixation, allow early range of motion for rehabilitation and are the treatment of choice for distal humerus fractures.

However, literature review shows that a number of important questions related to multifragmentary fractures distal humerus remain unanswered. Plating techniques and combined metal osteosynthesis are ineffective for multifragmentary and badly comminuted fractures. Wires can be used to reduce and fix smaller bone fragments [78, 79, 80] but they fail to stabilize the fracture properly. Absence of additional immobilization can result in secondary bone displacement, disturbed articular congruity and resultant contracture. More solid stability of smaller fragments fixed with wires could have improved outcomes of patients with multifragmentary fractures of the distal humerus. The search for the solutions will be discussed in our next series.

\section{REFERENCES}

1. Khomiakov V.N. Analiz invalidnosti vsledstvie travm verkhnikh konechnostei v Ukraine za 2011 god [Analysis of the disability due to injuries of the upper limbs in Ukraine for 2011]. Ortopediia, Travmatologiia i Protezirovanie, 2013, no. 1 (590), pp. 94-97. (in Russian)

2. Kuptsova O.A., Baindurashvili A.G., Nikitin M.S. Prichiny neudovletvoritel'nykh rezul'tatov lecheniia detei s perelomami golovki myshchelka plechevoi kosti [The reasons of unsatisfactory results of treating children with fratures of the humeral condyle head]. Ortopediia, Travmatologiia i Vosstanovitel'naia Khirurgiia Detskogo Vozrasta, 2016, vol. 4, no. 1, pp. 11-16. (in Russian)

3. Milanov N.O., Zelianin A.S., Simakov V.I. Rekonstruktsiia distal'nogo otdela plechevoi kosti pri nesrosshikhsia i nepravil'no srosshikhsia vnutrisustavnykh perelomakh s ispol'zovaniem nadkostnichno-kortikal'nykh autotransplantatov na sosudistoi nozhke [Reconstrution of the distal humerus for nonunited and malunited intra-articular fractures using vascular-pedicle peroneal-cortical autografts]. Vestnik Travmatologii i Ortopedii im. N.I. Priorova, 2002, no. 2, pp. 49-53. (in Russian)

4. Naumenko L.Iu., Nosivets D.S. Analiz oshibok i oslozhnenii pri lechenii perelomov distal'nogo metaepifiza plechevoi kosti [Analysis of errors and complications when treating fractures of the distal humeral meta-epiphysis]. Visn. Ortopediï, Travmatologii ta Protezuvannia, 2009, no. 3, pp. 79-83. (in Ukrainian)

5. Popov V.A., Shuba V.I, Bilonozhenko A.V. Biomekhanicheskie aspekty stabil'no funktsional'nogo osteosinteza vnutrisustavnykh perelomov distal'nogo kontsa plechevoi kosti [Biomechanial aspects of stably functional osteosynthesis of intra-articular fractures of the distal humerus]. Travma, 2002, vol. 3, no. 3, pp. 247-252. (in Russian)

6. O’Driscoll S.W. Optimizing stability in distal humeral fracture fixation. J. Shoulder Elbow Surg., 2005, vol. 14, no. 1 Suppl. S. pp. 186S-195S. DOI: 10.1016/j.jse.2004.09.033.

7. Bets I.G. Khirurgicheskoe lechenie perelomov plechevoi kosti i biologicheskie aspekty osteosinteza [Surgical treatment of humeral fractures and biological aspects of osteosynthesis]. Travma, 2017, vol. 18, no. 6, pp. 167-173. (in Russian)

8. Zhabin G.I., Shakhizi Fuad Al', Fediunina S.Iu. Oskol'chatye perelomy myshchelka plecha u vzroslykh ( klassifikatsiia i pokazaniia $\mathrm{k}$ vyboru fiksatora) [Comminuted fractures of humeral condyle in adults (classification and indications for selecting a fixator)]. Travmatologiia i Ortopediia Rossii, 2003, no. 1, pp. 38-41. (in Russian)

9. Kliuchevskii V.V. Khirurgiia povrezhdenii: rukovodstvo po travmatologii i ortopedii [Surgery of injuries: manual for traumatology 
and orthopaedics]. Iaroslavl', Rybinskii dom, 2004, 703 p. (in Russian)

10.Naumenko L.Iu., Nosivets D.S. Individual'naia programma meditsinskoi reabilitatsii pri polnykh vnutrisustavnykh perelomakh distal'nogo metaepifiza plechevoi kosti [The individual program of medical rehabilitation for complete intra-articular fractures of the distal humeral meta-epiphysis]. Ukr. Zhurn. Ekstrem. Meditsini im. G.O. Mozhaєva, 2009, no. 2, pp. 75-78. (in Russian)

11.Nosivets D.S., Naumenko L.Iu. Opyt operativnogo lecheniia patsientov s vnutrisustavnymi perelomami distal'nogo otdela plechevoi kosti s ispol'zovaniem odnoploskostnogo apparata vneshnei fiksatsii s sharovym sharnirom [The experience of surgical treatment of patients with intra-articular fractures of distal humerus using an uniplanar external fixator with a ball hinge]. Lechenie sochetannykh travm i povrezhdenii konechnostei: tez. dokl. Vseros. Nauch.-prakt. Konf. [“Treatment of limb concomitant injuries and damages. Proc. All-Russian Scientific-Practical Conference]. Moscow, 2008, pp. 63-63. (in Russian)

12.Atalar A.C., Demirhan M., Salduz A., Kiliçoğlu O., Seyahi A. Functional results of the parallel-plate technique for complex distal humerus fractures. Acta Orthop. Traumatol. Turc., 2009, vol. 43, no. 1, pp. 21-27. DOI: 10.3944/AOTT.2009.021.

13.Birch P.C., Downing N.J., Holdsworth B.J. Elbow function of distal humerus fractures treated by internal fixation - long term results. J. Bone Joint Surg. Br., 2002, vol. 84-B, no. Suppl. II, pp. 190-190.

14.Mansat P. Les raideurs du coupe. Paris: Sauramps Medical, 2005, 103 p.

15.Khuzhanazarov I.E., Khodzhanov I.Iu. Osnovnye tendentsii pri lechenii posttravmaticheskikh deformatsii loktevogo sustava u detei (obzor literatury) [The main tendencies in treatment of the elbow posttraumatic deformities in children (Review of the literature)]. Genij Ortopedii, 2015, no. 1, pp. 75-83. (in Russian)

16.Chibirov G.M., Soldatov Iu.P. Lechenie bol'nykh s narusheniem funktsii loktevogo sustava, soprovozhdaiushchimsia posttravmaticheskim psevdoartrozom myshchelka plechevoi kosti [Treatment of patients with the elbow function disorder accompanied by posttraumatic pseudoarthrosis of humeral condyle]. Genij Ortopedii, 2013, no. 3, pp. 80-81. (in Russian)

17.Chibirov G.M., Soldatov Iu.P. Operativnoe lechenie bol'nykh s posledstviiami travm loktevogo sustava s primeneniem apparata Ilizarova [Surgical treatment of patients with consequenes of the elbow injuries using the Ilizarov fixator]. Sovremennye Problemy Nauki i Obrazovaniia, 2015, no. 5, pp. 85-85. (in Russian)

18.Korzh N.A., Dedukh N.V. Reparativnaia regeneratsiia kosti: sovremennyi vzgliad na problemu. Stadii regeneratsii (soobshch. 1) [Bone reparative regeneration: modern look at the problem. Regeneration stages (information 1)]. Ortopediia, Travmatologiia $i$ Protezirovanie, 2006, no. 1, pp. 77-84. (in Russian)

19.Okhotskii V.P., Sergeev S.V. Perelomy distal'nogo otdela plechevoi kosti [Fractures of the distal humerus]. Sovetskaia Meditsina, 1991, no. 4, pp. 83-87. (in Russian)

20.Gaiko G.V., Stafun S.S., Kurinnii I.M. Prichini i struktura invalidnosti vnaslidok travm verkhn'oï kintsivki [The causes and structure of disability due to the upper limb injuries]. "Likuvannia travm verkhn'oï kintsivki ta ïkh naslidkiv": mater. nauk.-prakt. konf. $z$ mizhnar. uchastiu ["Treatment of the upper limb injuries and their consequences". Proc. Scientific-practical Conference with international partiipation]. Kiev, 2007, pp. 15-16. (in Ukrainian)

21.Naumenko L.Iu., Nosivets D.S. Fizicheskaia reabilitatsiia bol'nykh s perelomami distal'nogo metaepifiza plechevoi kosti [Physical rehabilitation of patients with fractures of distal humeral meta-epiphysis]. Ortopediia, Travmatologiia i Protezirovanie, 2010, no. 3, pp. 40-43. (in Russian)

22.Helfet D.L., Hotchkiss R.N. Internal fixation of the distal humerus: a biomechanical comparison of methods. J. Orthop. Trauma, 1990, vol. 4, no. 3, pp. 260-264.

23.Ring D., Gulotta L., Jupiter J.B. Unstable nonunions of the distal part of the humerus. J. Bone Joint Surg. Am., 2003, vol. 85-A, no. 6, pp. 1040-1046.

24.Fuller D.A. Open Reduction, Internal Fixation Distal Intraarticular Distal Humerus Fracture. J. Orthop. Trauma, 2016, vol.30, no. Suppl 2, pp. S13-S14. DOI: 10.1097/BOT.0000000000000584.

25.Kaniuka V., Abramov V.V., Nekhanevich O.B. Aktual'nist' zastosuvannia zasobiv fizichnoï reabilitatsiï u vidnovnomu likuvanni khvorikh ta invalidiv z travmami verkhnikh kintsivok (ogliadi literaturi). [Relevance of using physical rehabilitation means in restorative treatment of patients and disabled persons with injuries of the upper limbs (Review of the literature)]. Vestnik Problem Biologii i Meditsiny, 2014, no. 1 (106), pp. 11-17. (in Ukrainian)

26.Solod E.I., Lazarev A.F., Tsykunov M.B., Dzhanibekov M.Kh. Optimizatsiia reabilitatsionnogo protsessa pri operativnom lechenii perelomov distal'nogo kontsa plecha [Rehabilitation process optimization for surgial treatment of fractures of the distal humeral end]. Vestnik Vosstanovitel'noi Meditsiny, 2015, no. 3(67), pp. 29-32. (in Russian)

27.Kalantyrskaia V.A., Kliuchevskii V.V., Perova V.A., Piskun M.S. Preduprezhdenie kontraktur pri lechenii povrezhdenii loktevogo sustava [Contrature prevention in treatment of the elbow injuries]. Politravma, 2015, no. 2, pp. 50-58. (in Russian)

28.Nosivets' D.S., Boiko I.V., Naumenko L.Iu. Suchasni pidkhodi do reabilitatsiï khvorikh z perelomami distal'nogo metaepifiza plechovoï kistki: (ogliad lit) [Current approahes to rehabilitation of patients with fratures of the distal humeral meta-epiphysis (Review of the literature)]. Visn. Ortopediï, Travmatologii ta Protezuvannia, 2009, no. 1, pp. 71-74. (in Ukrainian)

29.Joeris A., Lutz N., Blumenthal A., Slongo T., Audigé L. The AO Pediatric Comprehensive Classification of Long Bone Fractures (PCCF). Acta Orthop., 2017, vol. 88, no. 2, pp. 123-128. DOI: 10.1080/17453674.2016.1258533.

30.Jupiter J.B., Morrey B.F. Fractures of the distal humerus. In: Morrey B.F., ed. Elbow and its disorders. 3rd ed. Philadelphia: WB Saunders, 2000. P. 293-329.

31.Matelenok E.M., Grashchenkova T.N. Konservativnoe lechenie patsientov s perelomami myshchelka plechevoi kosti [Conservative 
treatment of patients with humeral condylar fractures]. Ortopediia, Travmatologiia i Protezirovanie, 2002, no. 2, pp. 48-51. (in Russian)

32.Matelenok E.M. Planirovanie i realizatsiia khirurgicheskikh vmeshatel'stv pri perelomakh myshchelka plechevoi kosti [Planning and realization of surgical interventions for fractures of humeral condyle]. Travma, 2006, vol. 7, no. 4, pp. 289-295. (in Russian)

33.Naumenko L.Iu., Nosivets D.S. Funktsional'nye rezul'taty konservativnykh i khirurgicheskikh sposobov lecheniia perelomov distal'nogo metaepifiza plechevoi kosti [Functional results of conservative and surgical techniques for treating fractures of distal humeral meta-epiphysis]. Ukr. Zhurnal Ekstrem. Meditsini im. G.O. Mozhaєva, 2010, vol. 11, no. 3, pp. 104-110. (in Russian)

34.Naumenko L.Iu., Nosivets D.S. Kharakteristika metodov konservativnogo lecheniia pri povrezhdeniiakh distal'nogo otdela plechevoi kosti [Characterization of the tehniques of conservative treatment for distal humeral injuries]. Travma, 2011, vol. 12, no. 2, pp. 87-90. (in Russian)

35.Shesternia N.A., Lazarev A.F., Ivannikov S.V., Zharova T.A., Solod E.I., Dzhanibekov M.Kh., Abdul A.M. Podkozhno-subfastsial'nyi osteosintez perelomov distal'nogo otdela plechevoi kosti [Subcutaneous-subfascial osteosynthesis of distal humeral fractures]. Kafedra Travmatologii i Ortopedii, 2017, no. 1(21), pp. 5-9. (in Russian)

36.Kalantyrskaia V.A., Kliuchevskii V.V., Perova V.A., Piskun M.S. Rekonstruktivnaia i plasticheskaia khirurgiia v lechenii povrezhdenii loktevogo sustava [Reconstuctive and plastic surgery in treatment of the elbow injuries]. Voprosy Rekonstruktivnoi i Plasticheskoi Khirurgii, 2015, vol. 18, no. 2(53), pp. 25-33. (in Russian)

37.Girshin S. G. Klinicheskie lektsii po neotlozhnoi travmatologii: uchebnoe rukovodstvo [Clinical lectures on emergency traumatology: training guide]. M., Azbuka, 2004, 544 p. (in Russian)

38.Zoria V.I., Babovnikov A.V. Povrezhdeniia loktevogo sustava [The elbow injuries]. M., GEOTAR-Media, 2010, 464 p. (in Russian)

39.Kazarezov M.V., Bauer I.V., Koroleva A.M. Travmatologiia, ortopediia i vosstanovitel'naia khirurgiia [Traumatology, orthopaedics and restorative surgery]. Novosibirsk, Briz, 2004, 288 p. (in Russian)

40.Bodnia A.I., Slavov V.Kh., Krivenko S.N. Apparat dlia vneshnego osteosinteza perelomov distal'noi treti plechevoi kosti [A device for external osteosynthesis of distal third humeral fractures]. Ortopediia, Travmatologiia i Protezirovanie, 2010, no. 4, pp. 60-64. (in Russian)

41.Kallaev T.I., Kallaev I.O. Biomekhanicheskoe obosnovanie kompressionnogo osteosinteza pri okolo- i vnutrisustavnykh perelomakh [Biomechanical substantiation of compression osteosynthesis for peri- and intraarticular fractures]. Vestn. Travmatologii i Ortopedii im. N. I. Priorova, 2002, no. 1, pp. 44-48. (in Russian)

42.Kallaev T.N. Chreskostnyi osteosintez okolosustavnykh i vnutrisustavnykh perelomov distal'nogo metaepifiza plechevoi kosti ustroistvom dinamicheskoi kompressii. Avtoref. Diss. kand. med. nauk [Transosseous osteosynthesis of periarticular and intraarticular fractures of distal humeral meta-epiphysis using a device of dynamic compression. Cand. med. sci. diss.]. Moscow, 2002. 22 p. (in Russian)

43.Dergachev V.V. Likuvannia perelomiv distal'nogo epimetafiza plechovoï kistki sterzhnevimi aparatami. Avtoref. Diss. kand. med. nauk [Treatment of distal humeral epi-metaphysis fractures using rod devices. Cand. med. sci. diss.]. Kharkiv, 2005. 20 p. (in Ukrainian)

44.Valiev E.Iu. Khirurgicheskoe lechenie bol'nykh s okolo- $i$ vnutrisustavnymi perelomami distal'nogo otdela plechevoi kosti. Avtoref. Diss. kand. med. nauk [Surgical treatment of patients with peri- and intraarticular fractures of distal humerus. Cand. med. sci. diss.]. Tashkent, 1994. 17 p. (in Russian)

45.Gorodnichenko A.I., Guseinov T.Sh., Uskov O.N. Chreskostnyi osteosintez perelomov distal'nogo otdela plechevoi kosti [Transosseous osteosynthesis of distal humeral fractures]. Khirurgiia. Zhurnal im. N.I. Pirogova, 2013, no. 3, pp.32-36. (in Russian)

46.Gorodnichenko A.I., Guseinov T.Sh., Uskov O.N. Khirurgicheskoe lechenie perelomov myshchelkov plechevoi kosti apparatami vneshnei fiksatsii [Surgical treatment of condylar humeral fractures with external fixators]. Kremlevskaia Meditsina. Klinicheskii Vestnik, 2015, no. 4, pp. 67-70. (in Russian)

47.Kvasha V.P. Lechenie perelomov distal'nogo kontsa plechevoi kosti u vzroslykh [Treatment of humeral distal end fractures in adults]. Lechenie povrezhdenii i zabolevanii oporno-dvigatel'nogo apparata metodom chreskostnogo osteosinteza po Ilizarovu: sb. nauch. tr. [Proc. "Treatment of the locomotorium injuries and diseases by transosseous osteosynthesis method according to Ilizarov"]. Kazan', 1992, ch. 2, pp. 135-138. (in Russian)

48.Kniazevich V.S. Operativnoe lechenie perelomov plechevoi kosti sterzhnevym apparatom Furdiuka i spitsesterzhnevym apparatom. Avtoref. Diss. kand. med. nauk [Surgical treatment of humeral fractures using the Furdiuk rod device and a wire-rod device. Cand. med. sci. diss.]. Mosow, 2005. 19 p. (in Russian)

49.Krylov V.A. Lechenie bol'nykh s zakrytymi vnutrisustavnymi perelomami myshchelka plechevoi kosti metodami chreskostnogo $i$ nakostnogo osteosintezov. Avtoref. Diss. kand. med. nauk [Treatment of patients with closed intraarticular fractures of humeral condyle by methods of transosseous and internal osteosyntheses. Cand. med. sci. diss.]. Kurgan, 2009. 23 p. (in Russian)

50.Dergachev V.V. Repozitsionnye i funktsional'nye vozmozhnosti sterzhne-spitsevogo apparata pri vnutrisustavnykh perelomakh plechevoi kosti [Repositional and functional potentials of a wire-rod device for intraartiular humeral fractures]. Travma, 2002, vol. 3, no. 2, pp. 234-238. (in Russian)

51.Anglen J. Distal humerus fractures. J. Am. Acad. Orthop. Surg., 2005, vol. 13, no. 5, pp. 291-297.

52.Sanchez-Sotelo J., Torchia M.E., O’Driscoll S.W. Complex distal humeral fractures: internal fixation with a principle-based parallelplate technique. J. Bone Joint Surg. Am., 2007, vol. 89, no. 5, pp. 961-969. DOI: 10.2106/JBJS.E.01311. 
53.Naumenko L.Iu., Nosivets D.S. Sravnitel'naia kharakteristika metodov operativnogo lecheniia pri perelomakh distal'nogo metaepifiza plechevoi kosti [A comparative characteristic of the methods of surgical treatment for fractures of distal humeral metaepiphysis]. Travma, 2009, vol. 10, no. 3, pp. 301-307. (in Russian)

54.Sulima V.S., Omel'chuk V.P., Iuriichuk L.M., Valavina Iu.D. Perevagi khirurgichnogo likuvannia khvorikh z vnutrishn'o suglobovimi perelomami distal'nogo kintsia plechovoï kistki [Advantages of surgical treatment of patients with intraarticular fractures of distal humeral end]. Visnik Ortopediï, Travmatologiï ta Protezuvannia, 2006, no. 2, pp. 39-42. (in Ukraininan)

55.Zwingmann J., Neumann M.V., Hammer T.O., Reising K., Südkamp N.P. Comminuted Fracture of Elbow - Ostheosynthesis vs. Total Joint Replacement. Acta Chir. Orthop. Traumatol. Cech., 2016, vol. 83, no. 4, pp. 231-237.

56.Dubrov E.Ia. Perelomy i vyvikhi: atlas rentgenogramm [Fractures and dislocations: X-ray atlas]. M., MIA, 2007, 216 p. (in Russian) 57.Zhabin G.I., Shakhizi Fuad Al', Fediunina S.Iu. Operativnoe lechenie oskol'chatykh perelomov myshchelka plecha tipa S po klassifikatsii AO/ASIF [Surgical treatment of Type C comminuted condylar humeral fractures according to AO/ASIF classification]. Vestn. Travmatologii i Ortopedii im. N.N. Priorova, 2003, no. 3, pp. 53-57. (in Russian)

58.Barabash A.P., Grazhdanov K.A., comp. Lechenie perelomov distal'nogo otdela plechevoi kosti: federal'nye klinicheskie rekomendatsii [Treatment of distal humeral fractures: federal clinical tehnique manual]. Saratov, 2013, 21 p. (in Russian)

59.Russell G.V. Jr, Jarrett C.A., Jones C.B., Cole P.A., Gates J. Management of distal humerus fractures with minifragment fixation. J. Orthop. Trauma, 2005, vol. 19, no. 7, pp. 474-479.

60.Kalantyrskaia V.A., Golubev I.O. Operativnye dostupy pri lechenii vnutrisustavnykh perelomov kostei, obrazuiushchikh loktevoi sustav [Surgical approahes in treatment of fractures of the bones forming the elbow]. Vestnik Travmatologii $i$ Ortopedii im. N.N. Priorova, 2015, no. 4, pp. 65-69. (in Russian)

61.Vitiugov V.A., Kotenko V.V., Vitiugov B.I. Operativnoe lechenie perelomov distal'nogo kontsa plechevoi kosti [Surgical treatment of distal humeral fractures]. Ortopediia, Travmatologiia i Protezirovanie, 1986, no. 1, pp. 56-61. (in Russian)

62.Weber B.G., Vasey H. Osteosynthesis in Olecranon Fractures. Z. Unfallmed. Berufskr., 1963, vol. 56, pp. 90-96.

63.Kliuchevskii V.V., Khassan Ben El' Khafi. Lechenie okolo- i vnutrisustavnykh perelomov distal'nogo otdela plechevoi kosti [Treatment of peri- and intraarticular fractures of distal humerus]. Travmatologiia i Ortopediia Rossii, 2010, no. 3(57), pp. 96-102. (in Russian)

64.Naumenko L.Iu., Nosivets D.S. Operativnoe lechenie patsientov s perelomami distal'nogo metaepifiza plechevoi kosti metodom kombinirovannogo osteosinteza [Surgical treatment of patients with fractures of distal humeral meta-epiphysis by the method of combined osteosynthesis]. Travmatologiia i Ortopediia Rossii, 2009, no. 1(51), pp. 16-20. (in Russian)

65.McKee M.D., Veillette C.J., Hall J.A., Schemitsch E.H., Wild L.M., McCormack R., Perey B., Goetz T., Zomar M., Moon K., Mandel S., Petit S., Guy P., Leung I. A multicenter, prospective, randomized, controlled trial of open reduction-internal fixation versus total elbow arthroplasty for displaced intra-articular distal humeral fractures in elderly patients. J. Shoulder Elbow Surg., 2009, vol. 18, no. 1, pp. 3-12. DOI: 10.1016/j.jse.2008.06.005.

66.Nosivets D.S., Boiko I.V., Naumenko L.Iu. Kombinirovannyi osteosintez v reabilitatsii patsientov s vnutrisustavnymi perelomami distal'nogo metaepifiza plechevoi kosti [Combined osteosynthesis in rehabilitation of patients with intraarticular fractures of distal humeral meta-epiphysis]. Ortopediia, Travmatologiia i Protezirovanie, 2008, no. 4, pp. 108-111. (in Russian)

67.Nosivets D.S., Naumenko L.Iu. Preimushchestva kombinirovannogo osteosinteza v lechenii patsientov s vnutrisustavnymi perelomami distal'nogo metaepifiza plechevoi kosti [Combined osteosynthesis advantages in treatment of patients with intraarticular fractures of distal humeral meta-epiphysis]. Visn. Mors'koï Meditsini, 2009, no. 2, pp.108-113. (in Russian)

68.Zagorodnii N.V., Lomtatidze E.Sh., Sergeev S.V., Morozov D.S., Markin V.A., Ali Munassar Mansur. Operativnoe lechenie okolo- i vnutrisustavnykh perelomov plechevoi kosti s ispol'zovaniem blokiruemykh plastin [Surgical treatment of peri- and intraarticular humeral fractures using locked plates]. Meditsina Kriticheskikh Sostoianii, 2008, no. 4, pp. 3-7. (in Russian)

69.Golka G.G., Palamarchuk V.V., Bulavin K.A., Belostotskii A.I., Sukhovetskii V.V. Opyt primeneniia plastin s uglovoi stabil'nost'iu v lechenii vnutrisustavnykh perelomov [The experience of using plates with angular stability for treatment of intraarticular fractures]. Travma, 2010, vol. 11, no. 4, pp. 421-425. (in Russian)

70.Popov V.A., Shuba V.I., Bilonozhenko A.V. Taktika operativnogo likuvannia povnikh vnutrishn'osuglobovikh perelomiv distal'nogo kintsia plechovoï kistki ta ïkh obgruntuvannia [The tactics of surgical treatment of complete intraarticular fractures of distal humeral end and their rationale]. Visn. Ortopediï, Travmatologiï ta Protezuvannia, 2001. №. 4. S. 5-8. (in Ukrainian)

71.Atalar A.C., Tunalı O., Erşen A., Kapıcıoğlu M., Sağlam Y., Demirhan M.S. Biomechanical comparison of orthogonal versus parallel double plating systems in intraarticular distal humerus fractures. Acta Orthop. Traumatol. Turc., 2017, vol. 51, no. 1, pp. 23-28. DOI: 10.1016/j.aott.2016.11.001.

72.Parmaksızoğlu A.S., Özkaya U., Bilgili F., Mutlu H., Çetin Ü. Fixation of extra-articular distal humeral fractures with a lateral approach and a locked plate: an alternative method. Acta Orthop. Traumatol. Turc., 2016, vol. 50, no. 2, pp. 132-138. DOI: 10.3944/ AOTT.2015.14.0445.

73.Flinkkilä T., Toimela J., Sirniö K., Leppilahti J. Results of parallel plate fixation of comminuted intra-articular distal humeral fractures. J. Shoulder Elbow Surg., 2014, vol. 23, no. 5, pp. 701-707. DOI: 10.1016/j.jse.2014.01.017.

74.Sarkhel S., Bhattacharyya S., Mukherjee S. Condylar orientation plating in comminuted intraarticular fractures of adult distal humerus. Indian J. Orthop., 2015, vol. 49, no. 5, pp. 523-528. DOI: 10.4103/0019-5413.164046.

75.Buijze G.A., Blankevoort L., Tuijthof G.J. , Sierevelt I.N., Kloen P. Biomechanical evaluation of fixation of comminuted olecranon 
fractures: one-third tubular versus locking compression plating. Arch. Orthop. Trauma Surg., 2010, vol. 130, no. 4, pp. $459-464$. DOI: 10.1007/s00402-009-0980-z.

76.Hillsboro O.R. Mayo Clinic Congruent Elbow Plate System Manual. Acumed, 2006. 20 p.

77.Kinik H., Atalar H., Mergen E. Management of distal humerus fractures in adults. Arch. Orthop. Trauma Surg., 1999, vol. 119, no. 7-8, pp. 467-469.

78.Merkulov V.N., Dorokhin A.I. Duisenov N.B. Lechenie detei i podrostkov s mnogooskol'chatymi perelomami distal'nogo otdela plechevoi kosti, poluchennymi v rezul'tate dorozhno-transportnykh proisshestvii [Treatment of patients and adolescents with the multifragmental fractures of distal humerus obtained as a result of traffic accidents]. Meditsina Katastrof, 2009, no. 1, pp. 39-41. (in Russian)

79.Merkulov V.N., Dorokhin A.I., Duisenov N.B. Lechenie tiazhelykh mnogooskol'chatykh perelomov distal'nogo otdela plechevoi kosti u podrostkov [Treatment of severe multifragmental fractures of distal humerus in adolescents]. Vestnik Travmatologii $i$ Ortopedii im.N.N.Priorova, 2008, no. 3, pp. 20-22. (in Russian)

80.Nemsadze V.P., Minenkov B.V., Tarsov N.I., Bazhanova N.N. Spitsevoi metallosintez pri lechenii chrezmyshchelkovykh i nadmyshchelkovykh perelomov plechevoi kosti u detei (kliniko-eksperimental'nye rezul'taty) [Wire metallosynthesis in treatment of transcondylar and epicondylar humeral fractures in children (clinical-experimental results)]. Detskaia Khirurgiia, 2008, no. 2, pp. 4-6. (in Russian)

Received: 28.02.2018

\section{Information about the authors:}

1. Sergei N. Krivenko, M.D., Ph.D., Professor, Donetsk Gorky National Medical University, Donetsk, Email: kryvenkosn@yandex.ru

2.Dmitrii I. Medvedev, M.D., Ph.D., Donetsk Republican Trauma Center, Donetsk, Email: medvedev2557@rambler.ru 